\title{
Implementasi Sekolah Ramah Anak di Sd Ummul Quro Kota Semarang
}

\author{
Martien Herna Susanti ${ }^{1}$, Maman Rachman ${ }^{2}$, Ananda $^{3}$ \\ Prodi Pendidikan Pancasila dan Kewarganegaraan, Universitas Negeri Semarang ${ }^{1,2,3}$
}

\begin{tabular}{l} 
Informasi Artikel \\
\hline Hisrtory of Article \\
Received 2020-10-27 \\
Accepted 2021-01-26 \\
Pusblished 2021-01-31
\end{tabular}

Kata kunci :

Kurikulum Holistik, Sekolah Ramah Anak, Full Day School

Keywords:

Holistic Curriculum, Child Friendly School, Full Day School

\begin{abstract}
Abstrak
Penelitian ini membahas implementasi sekolah ramah anak dan hambatan dalam implementasi sekolah ramah anak di SD Ummul Quro Kota Semarang. Penelitian menggunakan desain penelitian deskriptif. Pemilihan lokasi penelitian di SD Ummul Quro Kota Semarang, karena memiliki sistem pendidikan full day school yang menerapkan kurikulum holistik yaitu memadukan sciencetech, religy, dan life skill. Hasil penelitian menunjukkan, SD Ummul Quro telah memenuhi kriteria sekolah ramah anak yang ditunjukkan: (1) deklarasi sebagai sekolah ramah anak pada tanggal 8 Februari 2020, (2) implementasi kurikulum, (3) pendidik dan tenaga kependidikan yang mengikuti pelatihan tentang hak-hak anak, (4) sarana dan prasarana yang mendukung, (5) partisipasi anak, dan (6) partisipasi orang tua dalam implementasi sekolah ramah anak. Hambatan implementasi sekolah ramah anak, yaitu: (1) belum tersedia mekanisme pengaduan dan penanganan kasus pelanggaran hak anak, (2) belum semua tenaga pendidik dan kependidikan mengikuti pelatihan, (3) belum tersedia tenaga konseling yang terlatih, (4) lingkungan fisik sekolah yang belum sepenuhnya aman, dan (5) belum adanya partisipasi lembaga masyarakat, alumni dan dunia usaha dalam mendukung program sekolah ramah anak.

\section{Abstract}

This study discusses the implementation of child-friendly schools and obstacles in the implementation of child-friendly schools in SD Ummul Quro Semarang City. The choice of research location at SD Ummul Quro Semarang City is because it has a full day school education system that applies a holistic curriculum, which combines sciencetech, religy, and life skills. The results showed that SD Ummul Quro had met the criteria for a childfriendly school which was shown: (1) the declaration as a child-friendly school on February 8, 2020, (2) curriculum implementation, (3) educators and education personnel who attended training on rights children, (4) supporting facilities and infrastructure, (5) children's participation, and (6) parents' participation in implementing child-friendly schools. Obstacles to the implementation of child-friendly schools, namely: (1) there is no mechanism for complaints and handling cases of violations of children's rights, (2) not all educators and education personnel have attended training, (3) trained counseling personnel are not yet available, (4) the physical environment of the school which is not completely safe, and (5) there is no participation of community institutions, alumni, and the business world in supporting child-friendly school program
\end{abstract}

(C) 2019, Universitas Negeri Semarang 


\section{PENDAHULUAN}

Artikel ini akan mendeskripsikan implementasi sekolah ramah anak dan hambatan dalam implementasi sekolah ramah anak di SD 2002).

Ummul Quro Kota Semarang. Istilah sekolah ramah anak diperkenalkan oleh UNICEF dengan istilah Child-Friendly School (CFS), yaitu sekolah inklusif, berpusat pada anak, dan peka gender. Sekolah ini menekankan efektivitas mengajar dan ada keterlibatan masyarakat. Model CFS bertujuan inf mendorong sekolah dan sistem pendidikan untuk ber bergerak secara progresif menuju standar kualitas untuk memastikan perkembangan seluruh anak ana (UNICEF, 2010). Agar suasana kondusif tersebut tercipta, perlu diperhatikan beberapa aspek yaitu: (1) program sekolah yang sesuai; (2) lingkungan sekolah yang mendukung; dan (3) aspek saranaprasarana yang memadai. Mpho Modipane dan Mahlapahlapana Themane (2014) menyebutkan, kor bahwa pendekatan CFS ditujukan untuk membuat sekolah berfungsi lebih baik untuk kesejahteraan ten anak yaitu menciptakan lingkungan pendidikan yang aman, sehat, melindungi anak, dan berkualitas.

Peraturan Menteri Negara Pemberdayaan Perempuan dan Perlindungan Anak Republik
Indonesia nomor 8 tahun 2014 tentang Kebijakan Sekolah Ramah Anak, pasal 1 ayat (2) menyebutkan, bahwa anak adalah seseorang yang belum berusia 18 (delapan belas) tahun, termasuk anak yang masih dalam kandungan. Hak Anak per merupakan bagian dari hak-hak asasi manusia ko yang wajib dijamin, dilindungi, dan dipenuhi oleh orang tua, keluarga, masyarakat, pemerintah, dan Pro negara. Tamar Schapiro (1999), mendefinisikan hat anak lebih

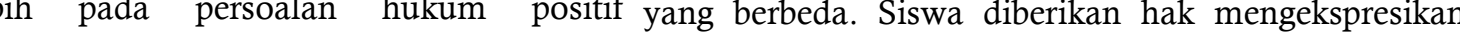
yang menetapkan, bahwa siapa pun di bawah usia pandangannya tentang sains, teknologi, seni, dan tujuh belas tahun dianggap sebagai anak dari sudut budaya, sehingga siswa merasa nyaman dan senang pandang negara. dalam proses belajar di sekolah (Utari, 2016). Selain itu,

Setiap anak berhak atas kelangsungan hidup, sekolah memastikan setiap siswa dapat menikmati tumbuh, dan berkembang serta berhak atas haknya dalam pendidikan tanpa diskriminasi terkait perlindungan dari kekerasan dan diskriminasi" disabilitas, jenis kelamin, etnis, agama, jenis kecerdasan, (Pasal 28B ayat (2) Undang- Undang Dasar Negara dan latar belakang orang tua.

Republik Indonesia Tahun 1945). Pasal 9 ayat (1) Sekolah ramah anak harus menciptakan situasi Undang-Undang Nomor 23 Tahun 2002 tentang sekolah yang aman, bersih dan sehat, memiliki perhatian Perlindungan Anak menegaskan, bahwa "Setiap atas budaya, lingkungan hidup, menghormati hak dan anak berhak memperoleh pendidikan dan melindungi siswa dari kekerasan, diskriminasi dan pengajaran dalam rangka pengembangan memastikan partisipasi siswa dalam perencanaan, terkait pribadinya". Anak di dalam dan di lingkungan kebijakan, pembelajaran, pengawasan, dan mekanisme 
pengaduan untuk pemenuhan hak dan dibandingkan dengan sekolah-sekolah pada perlindungan siswa (Iskandar, 2015). Penciptaan umumnya.

iklim sekolah ramah anak ini penting dengan Setiarini, Joyoatmojo dan Sunardi (2014) didasari pada pola pengalaman kehidupan sekolah, menyatakan dalam pelaksanaan full day school, orang-orang, dan mencerminkan norma, tujuan, pihak sekolah melakukan penyesuaian terhadap nilai, hubungan interpersonal, praktik belajar program akademik seperti penjadwalan mata mengajar, dan struktur organisasi (Thapa, Cohen, pelajaran, strategi pembelajaran, sarana dan Guffey, \& Higgins-D'Alessandro, 2013).SD prasarana yang memadai serta pendalaman materi, Ummul Quro merupakan salah satu sekolah dasar meliputi pengembangan struktur kurikulum, Islam terpadu di Kota Semarang yang telah penyusunan jadwal pelajaran, dan pelaksanaan mendeklarasikan sebagai sekolah ramah anak pada pembelajaran. Asyhar dan Susiati (2015) tanggal 8 Februari 2020 dengan melaksanakan menyatakan bahwa perkembangan siswa di pendidikan holistik, yaitu sciencetech, religy, dan life lingkungan full day school dengan kurikulum yang skill. Sekolah ini memadukan kurikulum didesain sedemikian rupa mampu mencetak siswa Pendidikan Nasional (Diknas) untuk berprestasi di bidang akademik lebih dari siswa di pengembangan keilmuawan (science) untuk ilmu sekolah biasa.

umum, kurikulum departemen agama untuk SD Ummul Quro sebagai full day school pengembangan keagaamaan dan kepribadian/ melaksanakan kegiatan pembelajaran 5 (lima) hari karakter Islam, serta kurikulum lokal (muatan kerja yaitu hari Senin sampai dengan Jumat lokal) untuk pengembangan keterampilan/vokasi dimulai pukul 07.00 hingga 15.15 WIB atau kurang berbasis karakter Islami dengan sistem full day lebih 8 (delapan) jam. Waktu yang relatif lama di school yang lebih memungkinkan terwujudnya sekolah menjadikan sekolah sebagai rumah kedua pendidikan utuh.

Hilalah (2009: 22) berpendapat bahwa full day school merupakan suatu proses pembelajaran yang dilaksanakan sehari penuh yang menerapkan dasar integrated curriculum dan integrated activity yang berarti hampir seluruh aktivitas anak berada di sekolah, mulai dari belajar, makan, bermain, dan ibadah di kemas dalam dunia pendidikan. Full day school menekankan pada komponen-komponen yang disusun dengan teratur dan baik untuk menunjang proses pendewasaan manusia (siswa) melalui upaya pengajaran dan pelatihan dengan waktu di sekolah yang lebih panjang atau lama bagi anak yang idealnya dapat memberikan rasa aman dan nyaman bagi anak untuk membantu proses mencari jati diri sekaligus mengekspresikan potensinya tidak semata-mata menguatkan aspek kognitif melainkan afektif dan psikomotorik peserta didik.. Hal tersebut sesuai dengan pernyataan Benyamin S. Blom (dalam Hasan, 2006: 114), bahwa sasaran (obyectivitas) pendidikan meliputi tiga bidang yakni kognitif, afektif dan psikomotorik. Berdasarkan uraian latar belakang di atas, maka permasalahan penelitian adalah: (1) Bagaimana implementasi sekolah ramah anak di SD Ummul Quro Kota Semarang?; (2) Apakah hambatan dalam implementasi sekolah ramah anak di SD Ummul Quro Kota Semarang 


\section{METODE}

Penelitian ini menggunakan desain deskriptif kualitatif (Bungin, 2015). Penelitian kualitatif dipilih, karena jenis penelitian ini selain menyediakan pemahaman, penjelasan, dan teori tentang perilaku sosial, juga dapat memahami implementasi kebijakan. Pendekatan ini bertujuan memperoleh informasi yang komprehensif, sistematis, dan mendalam dari kasus yang diteliti (Creswell, 2015), yaitu: (1) implementasi sekolah ramah anak di SD Ummul Quro Kota Semarang; dan (2) hambatan implementasi sekolah ramah anak di SD Ummul Quro Kota Semarang. Penelitian ini mengambil lokasi di SD Ummul Quro Kota Semarang sebagai salah satu sekolah dasar Islam terpadu yang mendeklarasikan sebagai sekolah ramah dengan sistem full day. Penelitian kualitatif memerlukan fokus, dikarenakan fokus berhubungan dengan konteks (Melvy, 2002). Dalam penelitian ini, konteks mencakup tempat dan waktu, aktor atau pelaku, serta peristiwa penting yang menjadi setting penelitian. Fokus penelitian meliputi: (1) kebijakan sekolah ramah anak; (2) pelaksanaan kurikulum; (3) pendidik dan tenaga kependidikan terlatih hak-hak anak; sarana dan prasarana sekolah ramah anak;

(3) partisipasi anak; dan (6) partisipasi orang tua, lembaga masyarakat, dunia usaha, pemangku kepentingan lainnya, dan alumni. Teknik sampling yang digunakan adalah purposive sampling dan snowball sampling (Sugiyono, 2009). Informan dalam penelitian ini yaitu: tenaga pendidik, tenaga kependidikan, dan siswa. Metode pengumpulan data yang dibandingkan dalam penelitian ini adalah metode observasi, wawancara, dan dokumentasi. Data yang terkumpul diuji validitasnya dengan menggunakan triangulasi (Ahmadi, 2016; Miles dan Huberman 1992:434)

\section{HASIL DAN PEMBAHASAN}

\section{Pelaksanaan Sekolah Ramah Anak di SD Ummul Quro Kota Semarang}

Waktu yang dihabiskan oleh anak delapan jam dalam sehari atau setara dengan satu per tiga hari mewajibkan sekolah untuk memprioritaskan perlindungan kepada anak yang dilakukan bersama-sama oleh semua unsur yang ada di sekolah mulai kepala sekolah, guru, guru bimbingan konseling, dan penjaga sekolah. Selain itu perlu adanya kerjasama yang baik dan terarah antara sekolah dengan orang tua, lembaga masyarakat, dunia usaha maupun alumni untuk memberikan rasa nyaman dan perlindungan hak-hak anak di sekolah melalui sekolah ramah anak. Saat ini Kota Semarang berhasil meningkatkan "Kategori Madya" di tahun 2018 menjadi "Kategori Nindya" di tahun 2019 dalam menuju Kota Layak Anak (KLA). Sekolah ramah anak merupakan indikator KLA dan menjadi bagian terpenting dari diterbitkannya kebijakan sekolah ramah anak sebagai upaya agar pemenuhan hak-hak anak.

Terdapat enam indikator yang digunakan untuk mengetahui sejauh mana implementasi sekolah ramah anak di SD Ummul Quro, yaitu: Pertama, kebijakan sekolah ramah anak. SD Ummul Quro dideklarasikan sebagai sekolah ramah anak pada tanggal 8 Februari 2020. Kegiatan pembelajaran di sekolah dilaksanakan 5 (lima) hari kerja dimulai pukul 07.00 sampai dengan 15.15 WIB atau kurang lebih 8 (delapan) jam. Setiap pagi anak- anak dibiasakan untuk sholat Dhuha dan hafalan Al'Quran Juz Amma sebelum melakukan aktivitas belajar rutin. Kegiatan keagamaan yang lain adalah pembiasaan sholat wajib dan sunnah dengan bacaan yang benar serta baca tulis Al Quran (Yanbu'a dan Qiro'ati).

Jam istirahat siswa diisi dengan pembiasaan ibadah shalat Duhur berjamaah, dilanjutkan dengan makan siang bersama, dan tidur siang. Kegiatan belajar mengajar (KBM) dilanjutkan kembali sampai dengan waktu Ashar. Shalat ashar merupakan bagian dari pembelajaran. Pelaksanaan KBM dilakukan dengan suasana yang menyenangkan, sehingga anak-anak tidak terbebani dengan pelajaran dan waktu yang panjang di sekolah.

Kedua, pelaksanaan kurikulum. Sebelum dideklarasikan sebagai sekolah ramah anak, SD Ummul Quro telah menerapkan program Penguatan Pendidikan Karakter (PPK) yaitu mengintegrasikannya karakter baik dalam kegiatan pembiasaan, pembelajaran (intrakurikuler), kokurikuler, dan ekstrakurikuler. Dampak positif implementasi 
program penguatan pendidikan karakter adalah semakin menguatkan dan mengokohkan pendidikan karakter yang ada di sekolah. Berdasarkan hasil di lapangan, guru-guru mendukung deklarasi sekolah ramah anak, karena selama ini yang dilakukan dalam mendidik dan mengajar sudah sesuai dengan komponen sekolah ramah anak, sehingga para guru tidak merasa canggung dan terbebani dalam mendukung program ini. Program sekolah ramah anak sejalan dengan visi sekolah yaitu menghasilkan peserta didik yang berahlaqul karimah, cerdas, trampil dan kompetitif. Kurikulum yang digunakan selain kurikulum nasional (Kurikulum 2013), juga menggunakan kurikulum khas atau lokal, yaitu: tahsin, tahfiz Quran, dan bahasa Arab.

Selain kegiatan belajar mengajar, sekolah juga menyelenggarakan berbagai kegiatan ekstrakurikuler yang bertujuan untuk memfasilitasi dan mengembangkan minat dan bakat siswa. Kegiatan ekstrakurikuler tidak dilaksanakan di luar jam sekolah, namun dilaksanakan pada jam sekolah, yaitu setiap hari Selasa dan Kamis. Pilihan ekstrakurikuler hari Selasa yaitu bahasa Inggris, bahasa Arab, qiroah, rebana, matematika dan sains, kaligrafi, dan panahan. Pilihan ekstrakurikuler hari Kamis yaitu seni tari, seni suara, menggambar dan mewarnai, futsal, dan robotika. Anak-anak bebas memilih dua kegiatan esktrakurikuler yang disediakan, namun bagi siswa kelas 4 (empat) dan 5 (lima) diwajibkan mengikuti kegiatan kepramukaan.

Ketiga, pendidik dan tenaga kependidikan terlatih hak-hak anak. Berdasarkan hasil wawancara, belum semua guru memperoleh kesempatan memperoleh pelatihan terkait hak anak dan sekolah ramah anak. Hingga saat ini pelatihan baru diikuti oleh kepala sekolah SD/MI, SMP/Mts, dan SMA/MA yang telah mendeklarasikan sebagai sekolah ramah anak. Salah satunya yang diinisiasi oleh dinas Pemberdayaan Perempuan dan Perlindungan Anak dalam bentuk kegiatan pelatihan yang berjudul, "Pelatihan Konvensi Hak Anak (KHA) Kota Semarang Tahun 2020" yang dilaksanakan tanggal 12-13 Februari 2020.
Keempat, sarana dan prasarana. Sekolah yang terdiri dari dua lantai ini terlihat ramah dan bersih. Siswa menyimpan sepatu di tempat rak sepatu yang berada di depan kelas, sehingga ruang kelas selalu terjaga kebersihannya. Untuk menjaga kenyamanan anak di sekolah disediakan loker pribadi tempat menyimpan buku, perlengkapan sholat, dan menyimpan keperluan tidur seperti bantal dan boneka yang dibawa masing-masing anak dari rumah. Untuk sementara belum tersedia ruang khusus untuk tidur siang dan hanya tersedia tikar untuk sekedar duduk-duduk. Untuk keperluan makan siang, pihak sekolah menyediakan catering dan masingmasing anak memiliki alat makan dan minum yang sudah diberi nama. Dalam rangka menciptakan lingkungan sekolah yang bersih dan sehat, disediakan tempat sampah yang telah dibedakan antara sampah organik dan anorganik, serta tempat mencuci tangan. Kapasitas ruang kelas sesuai dengan fungsi ruang, jumlah murid, dan aktifitas murid (Rasio 1:30). Temperatur dan kelembaban ruang kelas nyaman untuk kegiatan belajar mengajar terutama terhindar dari gangguan silau dan pantulan sinar, kebisingan, dan pencahayaan dalam kelas yang cukup nyaman untuk proses kegiatan belajar mengajar. Kondisi di atas sangat ideal bagi anak-anak dalam mengikuti kegiatan belajar.

Terdapat kamar mandi khusus siswa laki- laki dan perempuan, yang didasarkan nilainilai ajaran Islam dan menjaga pergaulan antara kaum laki-laki (ikhwan) dan kaum perempuan (akhwat). Terdapat juga ruang perpustakaan, multimedia, dan Usaha Kesehatan Sekolah (UKS) yang berada di dekat kantor guru untuk memudahkan guru mengawasi jika ada siswa yang sakit. Untuk menunjang kegiatan olah raga, tersedia lapangan sekolah yang luas yang juga digunakan untuk kegiatan upacara bendera. SD Ummul Quro juga dilengkapi fasilitas kebun sekolah untuk kegiatan eksplorasi lingkungan selain memperkenalkan kepada anak tentang pemanfaatan lahan kosong di sekitar sekolah.

Kelima, partisipasi anak. Berdasarkan data di lapangan, para guru melibatkan siswa dalam menyusun aturan di kelas. Menurut 
Sjostrom \& Stein (dalam Ron Banks,1997), guru dapat bekerja sama dengan siswa untuk mengembangkan aturan di kelas yang efektif melawan intimidasi dalam menciptakan iklim sekolah yang menolak tindak kekerasan di sekolah, termasuk intervensi individual dengan pelaku intimidasi dan korban, implementasi kegiatan pembelajaran kooperatif untuk mengurangi isolasi sosial, dan peningkatan pengawasan orang dewasa pada waktu-waktu penting, misal jam istirahat atau makan siang. Partisipasi anak juga diwujudkan melalui penghargaan atas kreatifitas anak berupa hiasan yang ada di dalam kelas yang kesemuanya merupakan hasil karya siswa. Kegiatan menghias kelas tidak hanya dilakukan oleh siswa dengan bimbingan guru kelas, melainkan melibatkan orang tua murid. Hal ini menunjukkan penghargaan kepada kreasi, inovasi, kreatifitas anak, tanggung jawab, kemandirian, serta meningkatkan kepercayaan diri pada anak sekaligus mempererat komunikasi siswa dengan orang tua dan juga orang tua dengan guru-guru di sekolah.

Keenam partisipasi orang tua, lembaga masyarakat, dunia usaha, pemangku kepentingan lainnya, dan alumni. Pelaksanaan indikator keenam ini belum sepenuhnya dilakukan, karena masih terbatas pada partisipasi orang tua. Partisipasi orang tua ini diwujudkan dalam organisasia komite sekolah dan menghadiri rapat sekolah untuk membahas program-program di sekolah. Dalam kegiatan yang menghadirkan orang tua siswa ini, pihak sekolah menyampaikan laporan kebijakan dan program-program yang akan dilaksanakan maupun yang sudah dilaksanakan baik yang berasal dari Dinas Pendidikan Kota Semarang maupun dari pihak sekolah dan yayasan. Dengan demikian, orang tua telah dilibatkan dalam penyusunan program sekolah yang diharapkan dapat mendukung program sekolah khususnya dalam mewujudkan sekolah ramah anak. Komunikasi intens juga terjalin antara guru dan orang tua siswa melalui media whatshaap.

Peran aktif orang tua siswa dalam kegiatan sekolah tersebut, relevan dengan pendapat Olweus (1993) yang merinci pendekatan yang melibatkan intervensi di tingkat sekolah, kelas, dan individu, mencakup komponen-komponen berikut: (1) membagi kuisioner kepada orang dewasa dan siswa untuk memahami luasnya masalah, menjustifikasi upaya intervensi, sekaligus berfungsi sebagai tolok ukur dampak peningkatan iklim sekolah setelah dilakukan komponen intervensi; (2) meningkatkan kesadaran orang tua melalui kampanye dalam forum orang tua-guru, buletin, dan pada pertemuan-pertemuan lainnya. Tujuannya adalah untuk meningkatkan kesadaran orang tua akan pentingnya keterlibatan dan dukungan orang tua dalam keberhasilan tujuan program. Sinergi atara orang tua dan guru mutlak diperlukan dalam membimbing anak, karena di sekolah, guru tidak lagi menggunakan tindakan-tindakan kekerasan dalam mendisiplinkan siswa yang bisa terjadi dalam interaksi pendidik dengan siswa, demikian juga orang tua diharapkan melakukan hal yang sama ketika siswa di rumah. SD Ummul Quro belum melibatkan lembaga masyarakat, dunia usaha, pemangku kepentingan, dan alumni dalam program sekolah ramah anak ini.

\section{Hambatan Implementasi Sekolah Ramah Anak di Sd Ummul Quro Kota Semarang}

Sekolah adalah institusi yang memiliki mandat untuk menyelenggarakan proses pendidikan dan pembelajaran secara sistematis dan berkesinambungan. Para pendidik dan tenaga kependidikan di sekolah diharapkan menyelenggarakan pendidikan dan pembelajaran yang mampu memfasilitasi peserta didik berperilaku terpelajar yang ditampilkan dalam bentuk pencapaian prestasi akademik, menunjukkan perilaku yang beretika dan berakhlak mulia, dan memiliki motivasi belajar yang tinggi. Dalam kenyataannya masih terdapat adanya proses pendidikan yang menjadikan anak sebagai obyek dan guru sebagai pihak yang selalu benar sehingga berpotensi menimbulkan kejadian bullying di sekolah.

Kekhawatiran orang tua dan masyarakat akan maraknya kasus-kasus kekerasan yang menimpa anak di sekolah dapat diminimalisir melalui sekolah ramah anak. Berdasarkan data di lapangan terdapat beberapa kendala bagi SD Ummul Quro dalam melaksanakan program sekolah ramah anak. 
Pertama, belum tersedia mekanisme pengaduan dan penanganan kasus pelanggaran hak anak termasuk kasus kekerasan, termasuk kejahatan seksual dan lainnya. Mekanisme pengaduan ini sangat urgen, meskipun belum dijumpai kasus kekerasan dan seksual di sekolah ini. Adanya mekanisme pengaduan dan penanganan kasus, selain sebagai indikator dari komponen sekolah ramah anak juga memudahkan dalam mengukur efektifitas pelaksanaan sekolah ramah anak ini. Kedua, belum semua tenaga pendidik dan tenaga kependidikan mengikuti pelatihan hak anak dan sekolah ramah anak. Hal ini menyebabkan pelaksanaan program sekolah ramah anak belum dapat dilaksanakan secara maksimal. Ketiga, belum tersedia tenaga konseling/BP3 (Badan Penyelenggara Pendidikan) yang terlatih, konvensi hak anak, sekolah ramah anak, dan peserta didik yang memerlukan perlindungan khusus (misalnya: anak penyandang disabilitas). Mengingat terdapat anak berkebutuhan khusus yang menjadi siswa di SD Ummul Quro. Keempat, lingkungan fisik sekolah. Pagar sekolah yang berada di sebelah tebing yang kontur tanahnya gembur menjadikan rawan akan longsor. Berdasarkan observasi di lapangan pernah terjadi longsor yang menyebabkan pagar sekolah runtuh. Kelima, belum adanya partisipasi lembaga masyarakat, alumni, dan dunia usaha dalam penyelenggaraannya program sekolah ramah anak di SD Ummul Quro, mengingat deklarasi sebagai sekolah ramah anak masih belum lama dilakukan dan masih dalam rintisan membangun jejaring dengan lembaga masyarakat, alumni, dan dunia usaha dalam penyelenggaraannya.

\section{SIMPULAN}

SD Ummul Quro merupakan salah satu sekolah dasar Islam terpadu di Kota Semarang yang telah mendeklarasikan sekolah ramah anak melalui pendidikan holistik, yaitu sciencetech, religy, dan life skill. Idealnya sekolah sebagai rumah kedua bagi anak dapat memberikan rasa aman dan nyaman bagi anak untuk membantu proses mencari jati diri sekaligus mengekspresikan potensinya. SD Ummul Quro telah memenuhi 6 (enam) komponen persyaratan sekolah ramah anak yaitu kebijakan sekolah ramah anak, kurikulum, pendidik dan tenaga kependidikan terlatih hak- hak anak, sarana dan prasarana, partisipasi anak, dan partisipasi orang tua dalam mendukung pelaksanaan program tersebut. Hambatan implementasi sekolah ramah anak, yaitu: Pertama, belum tersedia mekanisme pengaduan dan penanganan kasus pelanggaran hak anak termasuk kasus kekerasan, termasuk kejahatan seksual dan lainnya. Kedua, belum semua tenaga pendidik dan tenaga kependidikan mengikuti pelatihan hak anak dan sekolah ramah anak. Ketiga, belum tersedia tenaga konseling/BP3 (Badan Penyelenggara Pendidikan) yang terlatih. Keempat, lingkungan fisik sekolah. Kelima, belum adanya partisipasi lembaga masyarakat, alumni, dan dunia usaha dalam penyelenggaraannya program sekolah ramah anak di SD Ummul Quro.

\section{DAFTAR PUSTAKA}

Ahmadi, Rulam. (2016). Metodologi Penelitian Kualitatif. Yogyakarta: Arruzz Media .

Asyhar, A., \&Susiati, P. (2015). Pelaksanaan Full Day School Sekolah Dasar Islam Terpadu Al Huda Kecamatan Sangkapura Kabupaten Gresik (Studi Problematika Perkembangan Sosial Peserta didik). Jurnal Cendekia, 1(1), 77-97.

Bungin, Burhan.: Penelitian Kualitatif Edisi Kedua. Jakarta: Prenada Media Grup (2016).

Creswell, John W. (2010). Research Design Pendekatan Kualitatif, Kuantitatif, dan Mixed. Terjemahan Achmad Fawaid. Yogyakarta: Pustaka Pelajar.

Creswell, John W. (2015). Penelitian Kualitatif \& Desain Riset Memilih Diantara Lima Pendekatan Edisi 3. Terjemahan Ahmad Lintang Lazuardi. Yogyakarta: Pustaka Pelajar.

Cross, dkk. (2011). Three-year results of the Friendly Schools whole-of- school intervention on children's bullying behavior. British Educational Research Journal Vol. 37, No. 1, February 2011, pp. 105-129 ISSN 0141-1926 (print)/ISSN 1469- 3518 (online). Routledge Taylor and Francis Group.

Hilalah, Nur. (2009). Tesis. Pelaksanaan Full Day School di SD Plus Nurul Hikmah Pamekasan (Telaah Problematika Perkembangan Sosial Peserta Didik).

Iskandar. (2015). Improving Creativity Teachers Learning, Jakarta: Bestari. 
King, Rlizabeth. (2019). Implications for the child friendly schools policy within Cambodia's cultural and primary school context. Asia-Pacific Journal of Teacher Education. Routledge Taylor and Francis Group.

Melvy, JM. (2014). Writing The Qualitative Dissertation Understanding by Doing.

Modipane, Mpho \& Mahlapahlapana:: Teachers' social capital as a resource for curriculum development: lessons learnt in the implementation of a Child-Friendly Schools programme. Themane South African Journal of Education, Volume 34, Number 4, November 2014.

Olweus, D. (1993). Bullying at School: What We Know What We Can Do. CambridgeMA: Blackwell Ed.

Peraturan Menteri Negara Pemberdayaan Perempuan dan Perlindungan Anak Republik Indonesia Nomor 8 Tahun 2014 tentang Kebijakan Sekolah Ramah AnakPratiwi,

Azizun Ajeng. (2014). Retrieved from http://uniqpost.com/50241/negaranegara-dengan-kasus-bullying-tertinggiindonesia-di-urutan-ke-2.

Schapiro, Tamar. (1999). What is Child? Ethics, Vol. 109, No. 4 (July 1999), pp. 715- 738.Published by: The University of Press Stable.

Chicago

L:

http://www.jstor.org/stable/10.1086/23 $\underline{3943}$.

Setiarini, I, N, Joyoatmojo, \& dan Sunardi. (2014). Penerapan Sistem Pembelajaran "Fun \& Full Day School untuk Meningkatkan Relegiusitas Peserta Didik di SD IT Al Islam Kudus. Jurnal Teknologi Pendidikan dan Pembelajaran, 2(2), 231-244.

Undang-Undang Dasar Negara Republik Indonesia Tahun 1945 Undang-
Undang Nomor 23 Tahun 2002 tentang Perlindungan Anak

UNICEF. (2010). UNICEF'S Child-Friendly Schools: Ethiopia Case Study. UNICEF (2010).

Utari, E, Ranti. (2016). Implementation of Child Friendly School Program In SMP Negeri 1 Tempuran Magelang District. Journal of Education Policy Issue 7 Vol. V: 